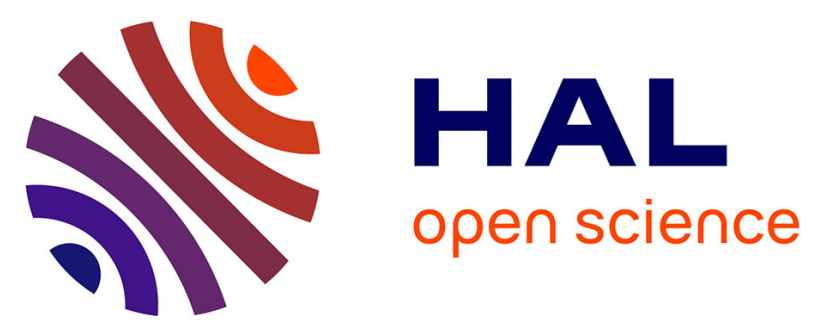

\title{
Optimization and performance comparisons of Induction and Synchronous Reluctance Machines considering the driving cycle of an electrical vehicle
}

Chao Liu, Guillaume Krebs, Philippe Dessante, Claude Marchand, Jean-Claude Vannier

\section{To cite this version:}

Chao Liu, Guillaume Krebs, Philippe Dessante, Claude Marchand, Jean-Claude Vannier. Optimization and performance comparisons of Induction and Synchronous Reluctance Machines considering the driving cycle of an electrical vehicle. 2015 IEEE International Electric Machines \& Drives Conference (IEMDC), May 2015, Coeur d'Alene, United States. 10.1109/IEMDC.2015.7409096 . hal-01282087

\section{HAL Id: hal-01282087}

https://hal-centralesupelec.archives-ouvertes.fr/hal-01282087

Submitted on 12 Mar 2020

HAL is a multi-disciplinary open access archive for the deposit and dissemination of scientific research documents, whether they are published or not. The documents may come from teaching and research institutions in France or abroad, or from public or private research centers.
L'archive ouverte pluridisciplinaire HAL, est destinée au dépôt et à la diffusion de documents scientifiques de niveau recherche, publiés ou non, émanant des établissements d'enseignement et de recherche français ou étrangers, des laboratoires publics ou privés. 


\section{Optimization and performance comparisons of Induction and Synchronous Reluctance Machines considering the driving cycle of an electrical vehicle}

\section{Abstract}

This paper aims at comparing the performances of induction and synchronous reluctance machines considering the driving cycle. The two machines have the same winding distributions on the stators and the same power inverters and batteries. The geometries and the electrical commands of these machines are optimized to minimize the total energy losses during the driving cycle. The methodology of the global optimization will be also presented in this paper.

\section{Introduction}

Today, the concerns of the energy crisis and the reduction of gas emissions stimulate the research in several electric vehicle (EV) domains. The traction in such vehicles require electrical motors with high efficiency, high ratio torque/mass, wide speed range, good overload performance under the limited battery capacity condition. As the cost of rare earth magnetic materials has increased significantly in recent years, electrical motors without permanent magnets draw more attention, such as induction motor (IM), doubly salient reluctance motor, wound-rotor synchronous motor or synchronous reluctance motor (SRM).

The IM is the most used motor in industrial applications, due to its low cost, robustness and the capability of self-starting [1,2]. Besides, in the case of traction applications, the fieldoriented controlled IM is certainly a good choice as they can be usefully flux-weakened [8]. From [3, 4], the SRM is considered as a possible alternative of IM even though it has not been adopted widely in industry market yet. Under the consideration of manufacturing cost and performances (power factor, energy efficiency, torque pulsation, etc), the transverse laminated synchronous reluctance motor (TLSyRM) is chosen to be studied as it presents the advantages like simple manufacturing process, flux weakening capability, comparable energy efficiency, etc $[5,6]$.

Several comparisons between IM and TLSyRM (Fig.1) have been presented in previous articles $[7,8,9]$ from the point of view of flux weakening capability, energy efficiency and this for different industrial applications. In this article, the two machines are compared from their energy efficiencies, the ratios torque/mass at different speeds, especially by optimizing the geometric and control parameters.

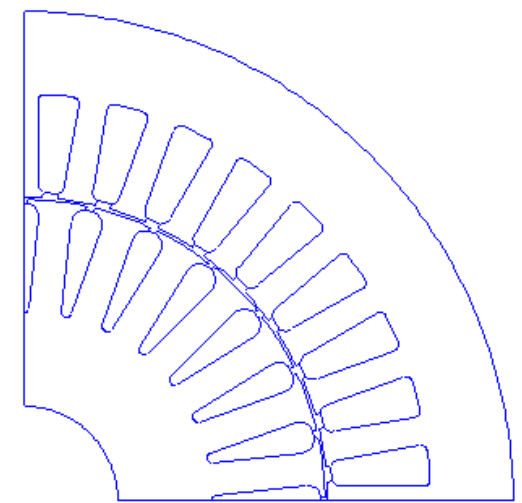

(a) IM

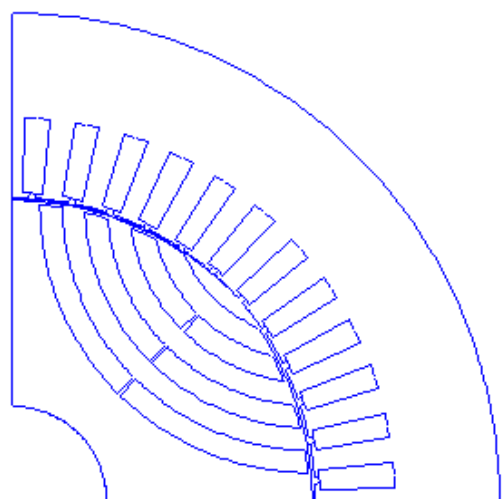

(b) TLSyRM

Fig. 1 Geometrical Structure of studied machines

\section{Electromagnetic modelling}

In this part, the electromechanical behaviors of the two motors, the steady-state loss of the inverter and of the motors are presented.

Chao Liu, Guillaume Krebs, Philippe Dessante, Claude Marchand, Jean-Claude Vannier. Optimization and performance comparisons of Induction and Synchronous Reluctance Machines considering the driving cycle of an electrical vehicle. 2015 IEEE International Electric Machines \& Drives Conference (IEMDC), May 2015, 
In order to optimize both machines with short computation times, the Finite Element Method (FEM) is not applied here. Nonlinear analytical models are then established and verified by FEM tools $[10,11]$.

The analytical model of IM is based on a lumped-parameter model and is supposed as a practical model for the conception procedure.

The adopted model calculates the consumed magneto-motive force (MMF) in every part of the machine, and combines it with an equivalent electrical schema [10]. This model is fast and reliable compared with harmonic FEM or time-domain FEM modeling. The copper losses in the stator and in the rotor are calculated. The iron losses are calculated with the help of the induction distribution in the air-gap given by the model.

A lumped-parameter model is no longer suitable for the SRM as there is no rotor current branch if the damper winding is not added. An analytical model of SRM [11] based directly on the Maxwell equations is used. As the IM model, it estimates the distribution of magnetic flux in the rotor by Faraday's Law, and constructs the nonlinear equations by Ampere's Law. However, only the fundamental of the MMF is considered, the slot effect is neglected and the torque pulsation as well.

The comparisons of torque calculation between analytical and FE models (see Fig.2) under different supplies show the reliability and precision of applied model. In Fig.2 (a) a three phase four-pole IM with single layer winding is modeled, while a four-pole SRM with the same winding is modeled in (b).

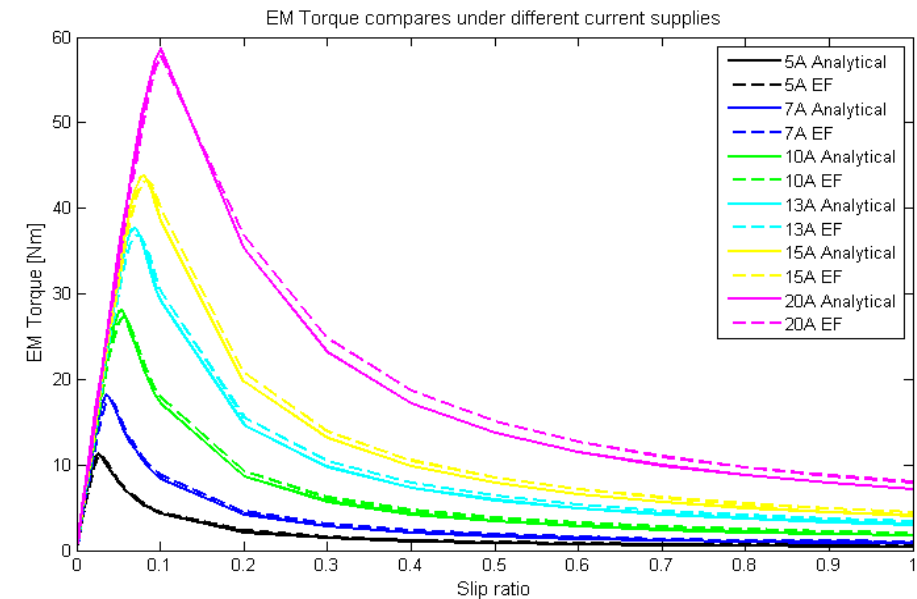

(a)

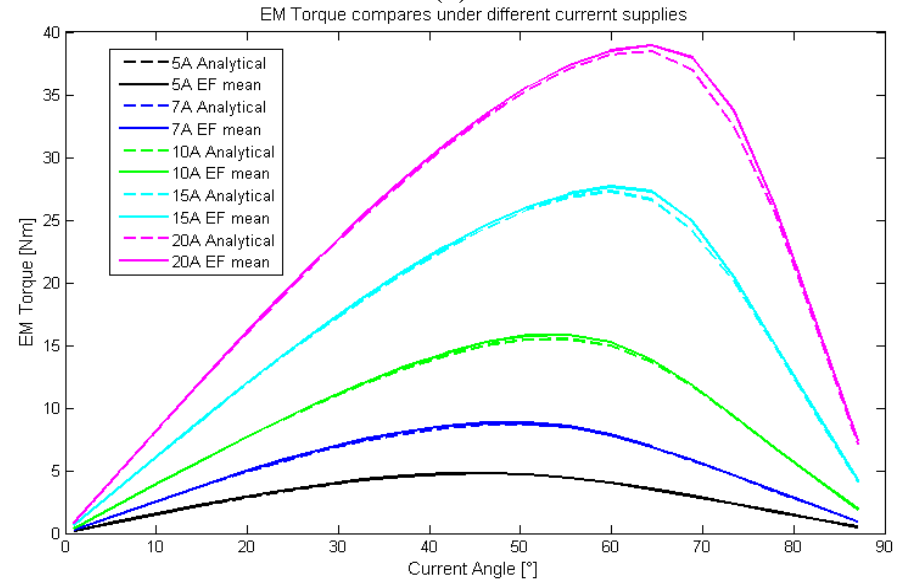

(b)

Fig. 2 Analytical model of (a) IM and (b) SRM validated by FEM

Chao Liu, Guillaume Krebs, Philippe Dessante, ${ }^{2}$ Claude Marchand, Jean-Claude Vannier. 
In an IM, the copper losses occur in both the stator and the rotor, while the iron losses occur in the stator and almost not in the rotor as the nominal slip ratio is weak. For SRM, the copper and iron losses occur mainly in the stator. When the rotor moves at a low or a medium speed, the copper losses shall be dominant. When it rotates at high speeds, the iron losses rise a lot. Hence, the loss modelling should be suitable in the whole frequency range $(e g, 50-1500 \mathrm{~Hz})$. The calculation of iron losses could be found in several references [14, 16]. The losses in the inverter are not negligible though they are determined by the phase current. The mechanical losses are considered in the loss modeling either.

\section{Global Conception}

The ARTEMIS European driving cycles are utilized to represent three real-world driving cycles (urban, rural and motorway) [12]. To avoid a long-term optimization, the $k$-means classification method (see [13]) is applied. The number of working points is compressed to only twelve, which offers an advantage of rapidity for the global optimization [14]. Else, to well represent the driving cycle, the "new" working points are assigned with different weights (calculated from the $k$-means clustering algorithm).

Since the inverter works with variable frequency, and variable current ranges, the regulation of electrical commands $\left(i_{d}, i_{q}\right)$ certainly influences the motor performance. Here, we optimize the commands and the geometries at the same time.

The differential evolution (DE) algorithm, is applied to optimize the motor geometries that minimize the total energy losses for all the working points. It is a metaheuristic optimization algorithm and it does not require differential optimization problem [15, 17]. In each individual of DE algorithm, another optimization with SQP algorithm is implemented to optimize the supply commands since there are only two variables and the optimization problem is monotone. The general optimization scheme is presented in Fig.3. The details of the optimization constraints and variables will be added in the complete paper.

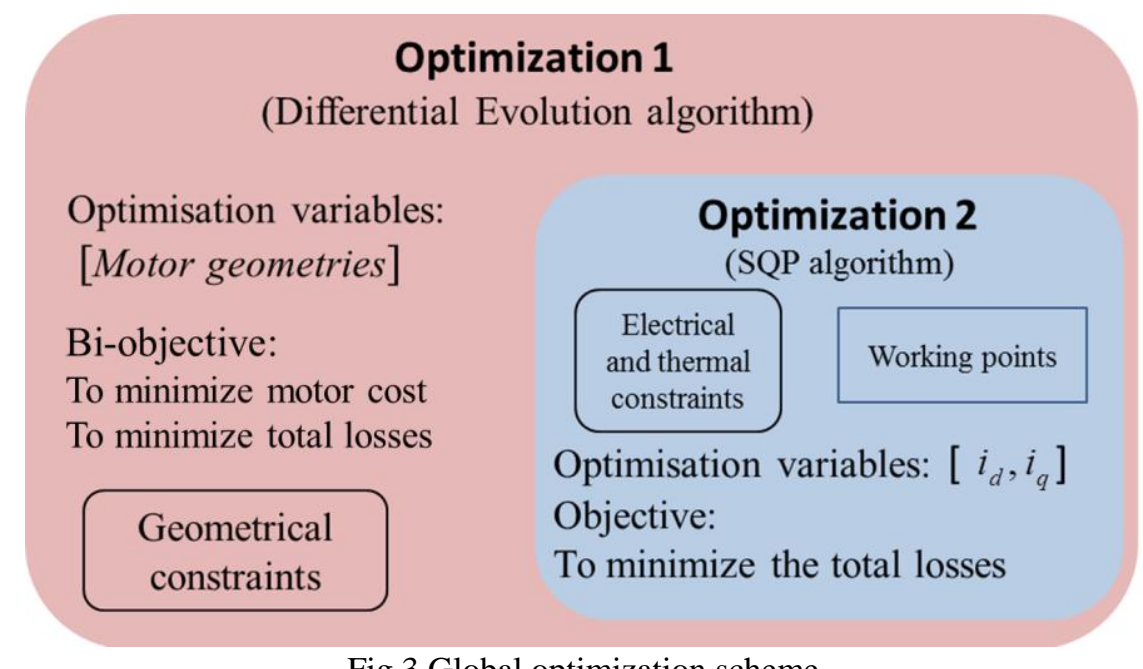

Fig.3 Global optimization scheme

Fig.4 presents the performance cartography of an optimized four-pole IM. The black nodes in the plans refer the selected working points with different weights. Applying optimization 2 , the optimal command for variable working range is presented in Fig.4 (a,b), which could be used as preliminary database of motor control design. From Fig.4 (c), IM is really competitive at high rotation speed. To improve the energy efficiency of IM at low speed, we consider raising the stator pole number.

Chao Liu, Guillaume Krebs, Philippe Dessante, Claude Marchand, Jean-Claude Vannier. 


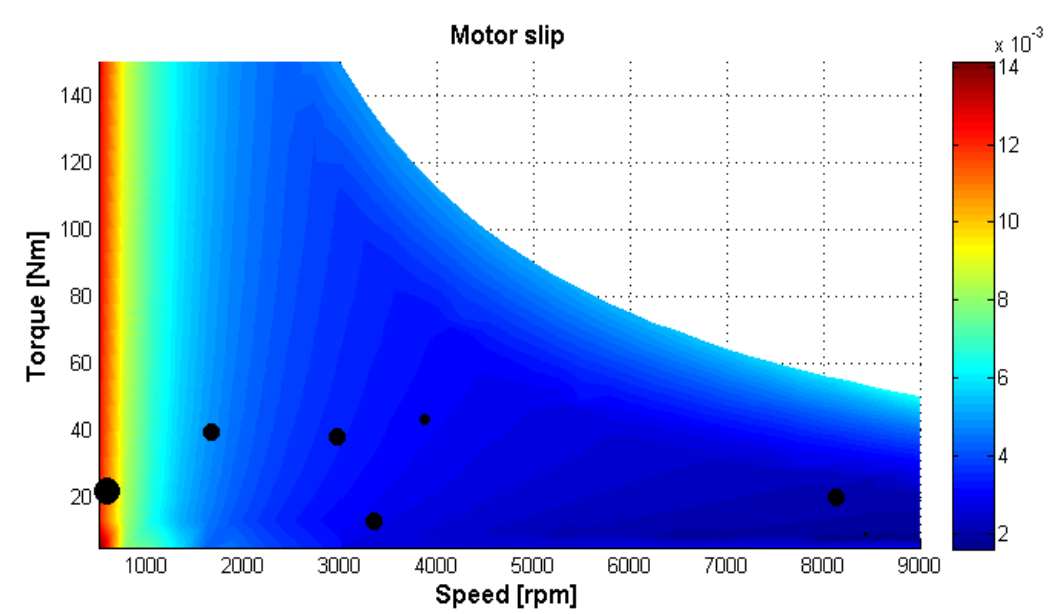

(a)

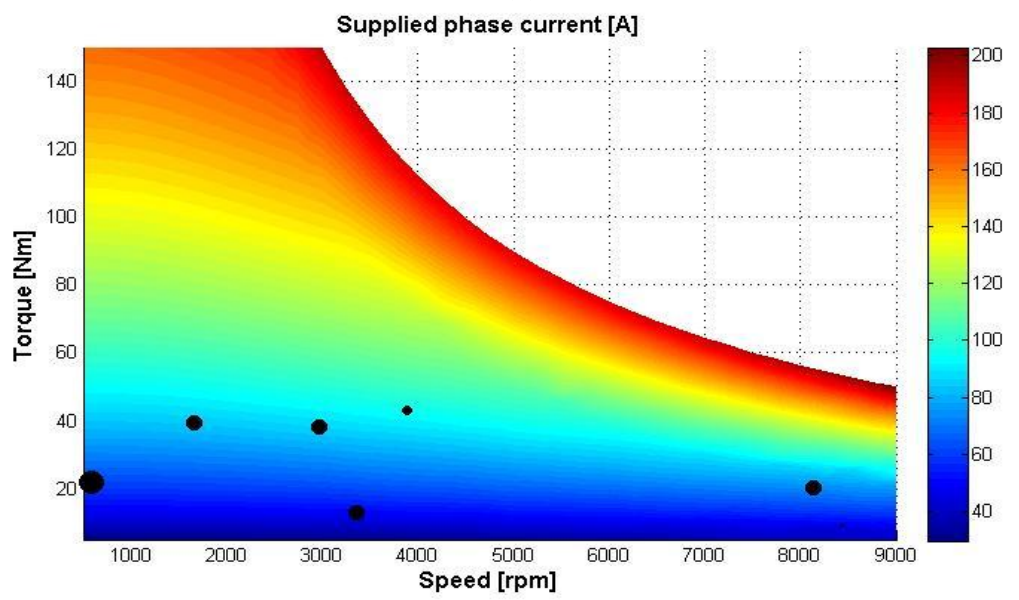

(b)

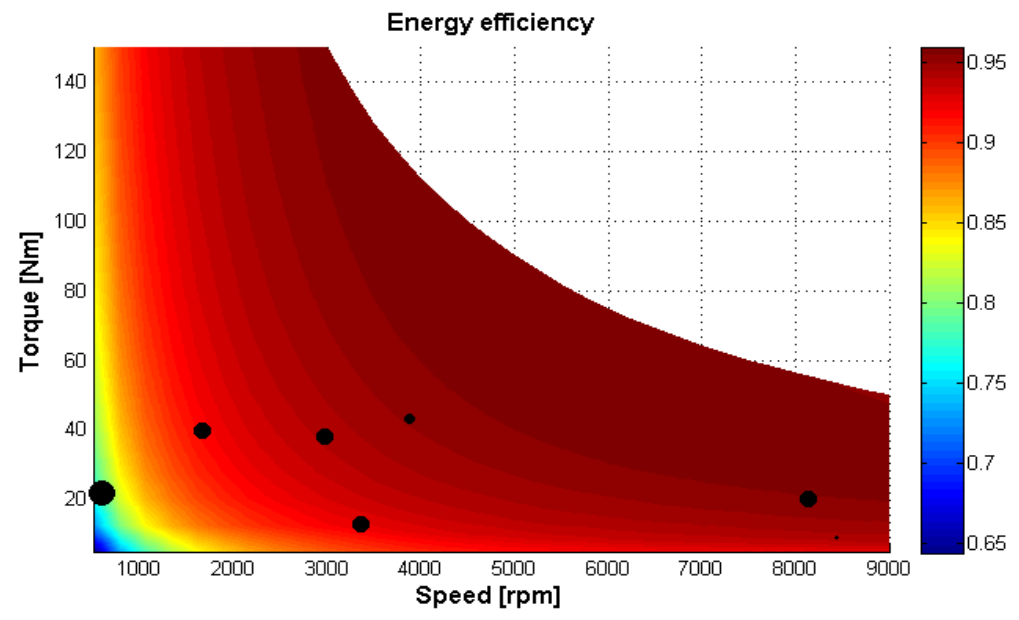

(c)

Fig.4 Optimal command parameters (slip ratio (a) and phase current amplitude (b)) (c) Optimal energy efficiency with electrical constraints of an optimized four-pole IM

\section{Conclusions}

In this paper, we propose a global optimization methodology to optimize the geometries and the electrical commands in term of losses and cost of an induction motor and of a transverse laminated synchronous reluctance motor. The two optimized motors will be compared from their mass, power factor, energy efficiency and thermal performance. This work could be used to judge the suitable low cost electrical motor for an EV application.

Chao Liu, Guillaume Krebs, Philippe Dessante, Claude Marchand, Jean-Claude Vannier. 


\section{References}

[1] Boldea and S. A. Nasar, "The Induction Machine Handbook. Boca Raton”, FL: CRC, 2002.

[2] P. L. Alger , "Induction machines, their behavior and uses", New York, Gordan and Breach, 1970.

[3] T. A. Lipo, "Synchronous reluctance machines - A variable alternative for AC drive?", Electric Machines and Power Systems - ELEC MACH POWER SYST 01/1991; 19(6):659671.

[4] J. Malan, M.J.Kamper, and P.N.T. Williams, "Reluctance synchronous machine drive for hybrid electric vehicle", IEEE International Symposium onIndustrial Electronics, 367 372 vol.2, 7-10 Jul 1998.

[5] J. Haataja, "A comparative performance study of four-pole induction motors and synchronous reluctance motors in variable speed drives", thesis in Lappeenranta University of Technology, 2003, Finland.

[6] T. Raminosoa, B. Blunier, Daniel Fodorean,and A. Miraoui, "Design and Comparison of High Speed Switched and Synchronous Reluctance Machines to Drive the Compressor of an Automotive PEM Fuel Cell”, ICEM, 2008.

[7] G. Franceschini, A. Fratta, and A. Vagati, G. Franceschini, "On the evolution of AC machines for spindle drive aplications", IEEE Transactions on Industry Applications, Vol. 28, No. 5, September/October 1992.

[8] A. Vagati, A. Fratta, and G. Franceschini, "AC motors for high-performance drives: a design-based comparison", IEEE Transactions on Industry Applications, Vol. 32, No. 5, September/October 1996.

[9] A. Boglietti, A. Cavagnino, M. Pastorelli and A. Vagati, "Experimental Comparison of Induction and Synchronous Reluctance Motors Performance", IEEE-IAS 40th Annual Meeting, Kowloon, Hongkong, 2-6 Oct. 2005, pp. 474-479.

[10] C. Liu, G. Krebs, P. Dessante, C. Marchand, and J.C. Vannier, "Modélisation comportemental non linéaire de moteurs asynchrones à cage pour le pré-dimensionnement", Symposium de Génie Electrique, 8-10 July 2014, ENS Cachan, France.

[11] D. Prieto, P. Dessante, J.C. Vannier, X. Jannot, J. Saint-Michel, "Modélisation analytique d'un moteur synchro-réluctant assisté d'aimants permanents", Symposium de Génie Electrique, 8-10 July 2014, ENS Cachan, France.

[12] M. André, "Real-world driving cycles for measuring cars pollutant emissions- Part A: The ARTEMIS Europeandriving cycles", Report INRETS-LTE 0411, June 2004.

[13] L. Reboul, "CH3 : Classification, Course. http://iml.univ-mrs.fr/ reboul/ADD4MAB.pdf".

[14] B. Dagusé, "Modélisation analytique pour le dimensionnement par optimisation d'une machine dédiée à une chaîne de traction hybride à dominante électrique ", thesis in Supélec, 2013, Gif (France).

[15] G. Pugsley, "Modélisation paramètrique non linéaires machines asynchrones et démarche d'optimisation associée", thesis in INPG, 2004,Grenoble (France).

[16] A. Boglietti, A. Cavagnino, M. Lazzari, M. Pastorelli, "Predicting iron losses in soft magnetic materials with arbitrary voltage supply: an engineering approach",IEEE Trans. on Magnetics, vol. 39, no 2, p. 981-989, March 2003.

[17] A. Qing, "Differential Evolution: Fundamentals and Applications in Electrical Engineering”, ISBN: 0470823925,Wiley-IEEE Press, July 2009.

Chao Liu, Guillaume Krebs, Philippe Dessante, Claude Marchand, Jean-Claude Vannier. Optimization and performance comparisons of Induction and Synchronous Reluctance Machines considering the driving cycle of an electrical vehicle. 2015 IEEE International Electric Machines \& Drives Conference (IEMDC), May 2015, Coeur d'Alene, United States. 10.1109/IEMDC.2015.7409096. hal-01282087 